\title{
Micro-learning Platforms Brand Awareness Using Social- media Marketing and Customer Brand Engagement
}

\author{
https://doi.org/10.3991/ijet.v16i17.23339
}

\author{
Alejandro Mujica-Luna, Esteban Villanueba, Manuel Luis Lodeiros-Zubiria $\left.{ }^{\square}\right)$ \\ Universidad Peruana de Ciencias Aplicadas, Lima, Peru \\ pccmmlod@upc.edu . pe
}

\begin{abstract}
This study aims to analyse the impact of Social Media Marketing in Customer Brand Engagement and Brand Awareness micro-learning platforms. The sample consisted of 220 students from micro-learning platforms using social media in the educational institutions. Because social-media marketing and customer brand- engagement are second-order reflexive constructions, the two-stage approach of hierarchical models with mode-A was adopted. The results reveal that social media marketing influences both the building of customer brand engagement and brand awareness among students on micro-learning platforms. Furthermore, it was shown that customer brand engagement is an important mediator between social media marketing and brand awareness. Social-media marketing activities carried out by micro-learning platforms contribute to the generation of customer brand engagement and brand awareness of these institutions. Furthermore, the results show that, although social-media marketing helps to generate brand awareness, it is through customer brand engagement that socialmedia marketing is most effective in generating brand awareness. For microlearning platforms, the results allow them to understand the importance of customer brand engagement when using social-media marketing to generate brand awareness.
\end{abstract}

Keywords - micro-learning, E-learning, MOOC, social media marketing, customer brand engagement, brand awareness, smart-PLS, latin america, secondorder, higher-order.

\section{Introduction}

Technological development is one of the most important trends defining society today, with the education sector being one of the most active in adopting it, and at the same time facing the most challenges [1]. On the one hand, digitalisation allows students access in a more democratic way to new educational content and skills development [1], required in various professional environments[2], but on the other hand, digitalisation makes educational institutions face the need to adapt their content and learning techniques to the needs of new students, as their way of learning has changed and technology plays a fundamental role in this change of behaviour. 
Within this digital transformation of education, one of the most evident changes is the development of e-learning, with Massive Open Online Courses (MOOCs) being one of the most popular educational techniques, as they are usually free or offered at modest prices[3]. These courses were first created by MIT and Harvard in 2012 [4] and nowadays they have become an educational phenomenon, where, thanks to technology [5], a large number of people can access quality education from any country in the world [6], as MOOCs are able to systematise, theorise, and develop electronic tools and services [1] that are flexible in terms of time, location or dedication [7], which allows for an increase in the ability to learn [8], improved academic performance of students [9] and increased satisfaction [10].

However, despite their popularity, MOOCs present some problems. The first problem faced by this type of online educational modality is the low course-completion rate [11], which often does not exceed 90\% [12]. The second problem faced by MOOC courses is the fact that many learners are only interested in the course videos [13] and are not interested in taking part in the assessments [12], [14] or obtaining a certificate [15].

To address this problem, different proposals for education have emerged in recent years, with micro-learning being one of the most interesting [16], [17], as evidenced by the fact that the number of academic studies on micro-learning has grown substantially in the last three years [18].

Micro-learning based courses can be considered as a particular case of MOOCs which are based on the transformation of e-learning content [19] using a learning model in which the course content, usually only videos, is distributed in short-duration formats through online, web or mobile platforms, which enables a higher attention-span of learners [20], [21]. As it is known, the attention-span of learners is now shorter [22] and micro-learning is better-suited to the needs of these new learners [23], as the learner only has to concentrate for short periods of time, while allowing them to expand their knowledge quickly [24], which results in better engagement by the learners [25].

Another advantage of micro-learning is its ability to better meet the needs of today's learners, as it often focuses on developing competences for a new job [26] or on filling a specific knowledge gap [21] that is accredited through micro-credentials [27]. Microlearning is also useful in continuing education within companies [28] as it has the advantage that employees trained using micro-learning can apply what they have learned immediately that they access the course. [29].

Turning to MOOCs, a third problem is related to the origin of the educational institutions that create them. As is well-known, the largest number of MOOC students are from Europe and the United States [6]; since the majority of MOOCs are taught in English, access for people who are not fluent in that language is limited, which prevents their globalisation [12].

In the specific case of Latin America, the region in which this study is focused, MOOCs have gained popularity, although as Baloco Navarro \& Barreto[30] state, there is still a long way to go in the region, as the number of students enrolled in these courses is limited. One of the reasons for the low popularity of MOOCs in Latin America is, on the one hand, their limited availability in the region [30], and on the other hand, as 
indicated above, the language barriers, as the number of courses taught in Spanish is low.

Faced with this lack of available educational MOOC courses in the region, educational ventures have recently emerged that seek, through the use of micro-learning, to facilitate access to knowledge and the improvement of the necessary skills for success in the labour market, which are accredited with the use of micro-credentials. In this sense, Peru has become a point of reference in the region, and currently two platforms of Peruvian origin, Netzun Plus and Crehana, have become points of reference in the dissemination of micro-learning mode courses in Latin America. In the case of Crehana [31] more than two million students follow its courses, while in the case of Netzun Plus, more than two hundred thousand students are enrolled in its micro-learning platform. [32].

A large part of the success of the expansion of these micro-learning platforms lies in the use of Social Media Marketing (SMM) as an important information channel for the education sector and its users [33] by allowing consumers to relate and interact individually with brands [2], [34], including the education sector [35], where the use of blogs or social networks to communicate [6] or create online reviews [35] is frequent.

Another reason that has also allowed the rise of these new players in the education sector has been their ability to generate good brand-awareness since, as is well known in the case of MOOC courses, the reputation of the organisation that creates the MOOC course is becoming increasingly important in order to ensure that students want to enrol in their courses [36], or to ensure that they subsequently continue to take more courses from the same institution [37]. Furthermore, it is worth noting that brand awareness is probably the most important brand equity variable in the early stages of a company [38], a case that fits the reality of micro-learning platforms, which have been in existence for less than five years. Likewise, brand-awareness is critical in the case of the target audiences of micro-learning platforms, young people, as it is known that consumers establish most of their preferences towards brands before the age of 25 [39], so that generating brand-awareness by micro-learning platforms in their target audience could guarantee the present and future preference of their students towards their brands.

At the same time, another variable that is relevant in the educational environment of micro-learning is Customer Brand Engagement (CBE), which is capable of generating customer satisfaction, brand attachment and loyalty [40], improved advertising effectiveness [41] and overall business performance [42]. This construct, like educational engagement, is made up of three dimensions, one cognitive, one emotional and one behavioural. [43]-[46].

As is well known, engagement has been identified as a research priority in the educational field [47], [48] and although the educational world has focused its study on the classroom environment [49], its study beyond the teaching environment is also a priority. In this sense, in a much more competitive environment, universities are paying more and more attention to the generation of marketing strategies [50] as, faced with the huge offer of MOOCs, students choose courses based on the institution's brand [51], so brand awareness, CBE and social media are essential to ensure their success.

In this sense, although the number of research studies on micro-learning has increased considerably in recent years, more research is still needed [52]. The same is 
true when talking about educational branding, because although it is known that branding is fundamental in any economic sector, including education, so far the number of studies that relate e-learning to branding in general are scarce [35], [53].

It is also worth mentioning that, although the relationship between SMM, brand awareness and CBE has been investigated in different categories [54], [55], the same does not happen in the e-learning environment, MOOCs or micro-learning platforms, so there is certainly a theoretical gap that needs to be filled. Based on the above, the present research aims to analyse the impact of SMM on CBE and brand awareness in students of micro-learning platforms.

\section{Literature review - Hypothesis}

\subsection{Social Media Marketing}

Educational institutions now must be market-orientated in order to be able to communicate with their current or potential students, and social media is a fundamental resource for this [56].

Regarding the dimensions that make up SMM, it is known that electronic-word-ofmouth (e-WOM) makes it possible to reduce the uncertainty of using a service, such as a course, thanks to the exchange of experiences by other consumers on social networks, whether positive or negative, about products and/or services offered by a brand [54], [57]. The most frequent actions related to e-WOM are the generation of blog content, or sharing opinions among those close-by [54], [58], [59], these actions being especially valued by potential students of MOOC courses. [35].

Relate to the second dimension of SMM, customisation, this is understood as the ability of social networks to provide personalised information to meet users' personal preferences [54], [55], [60] in order to create value [55], [61], [62] by delivering content to specific groups of users using personalised messages [55].

Concerning the third dimension, the entertainment trend, this measures how the brand delivers the latest, updated and modern information about the services and/or products it offers to its users [54], [63], through interesting, exciting and fun content and information [54], which generates trust in the brand [54], [55]. Some tools that are used to generate the entertainment trend are games, videos or the creation of contests [64] as all of them are known to be useful for generating entertaining experiences on social networks [55], which increases participation in the social network communities of brands [45], [55], [63]. In the case of MOOCs, it has been shown that the use of games, fun content and user enjoyment of the course content are key to the success of the course[65].

In the case of interaction, this is defined as the opportunity offered by social networks for two-way exchange of opinions and information [66], which allows consumers to exchange ideas with other users about specific products, services or brands [67] as happens in MOOC courses, where it has been observed that users use blogs [10] or Facebook to share experiences and knowledge, interact with teachers [68], as well as 
to make recommendations to people close to them [69], or spread knowledge and generate engagement. [4], [70].

Finally, some previous research has shown that SMM influences the achievement of brand equity, and brand awareness in particular [71]-[73]. In the case of education, it has been shown that SMM is able to improve the image of universities while at the same time generating brand awareness [74] or brand identification [75].

\subsection{Customer brand engagement}

Customer brand engagement has the ability to make consumers feel that a brand is part of them [76] and therefore want to engage with it beyond the mere purchase process [77], for example by sharing or communicating information to other consumers [44], [78], which usually results in improvement of an organisation's performance [79] or enhancing its competitive advantages [42]

Customer Brand Engagement (CBE) can be defined in different ways, although in this study we will use the definitions of Brodie et al. [44], Hollebeek [80] and Hollebeek et al. [81], who state that $\mathrm{CBE}$ is a psychological state that arises from interactive and co-creative experiences with a brand in relation to a service, which helps brands succeed, as users who show brand engagement actively recommend brands, generate positive word-of-mouth reports [82], [83], and come to defend them from attacks [84]. The reasons for CBE are cognitive, affective and behavioural [54], [85], [86]. These dimensions have also been identified as generating engagement in e-learning and MOOC courses [48], which is manifested in the presence of more participative students during the course [48], [87], who achieve better learning outcomes [47], who actively use the social networks of the courses [88] and who have a better academic relationship with the educational entity [89].

Regarding the dimensions of CBE, cognitive engagement is defined as a user's ability to think about a brand [81]. In the case of emotional engagement, this relates to a user's ability to emotionally bond with a brand [81], while behavioural engagement relates to the time and effort the consumer spends interacting and engaging with the brand [81], while behavioural engagement relates to the time and effort the consumer spends interacting and engaging with the brand [44], [81].

Some authors suggest that organisations can encourage consumer engagement through different marketing activities [90]-[92], including the use of social media. In that sense SMM has been proven to be an antecedent of CBE [93], as SMM allows companies, in varying degrees [54], to listen to their consumers, exchange information with them, or even influence conversations about their brands [71]. In the case of education, and more specifically in the micro-learning-platform sector, no relevant studies have been found which measure the relationship between SMM and CBE, although it is possible that this relationship exists, as has been proven in other economic sectors. Thus, the following hypothesis is proposed.

H1 - SMM impacts on the CBE of micro-learning-platform students 


\subsection{Brand awareness}

In the education sector there is ever more competition, and universities and other educational institutions have realised that having a strong and distinctive brand is essential. In this regard, it is known that brand-awareness is one of the most important dimensions of brand equity to achieve this [94], so all educational institutions should apply brand awareness or brand equity strategies in general, in order to improve their student recruitment and retention results, or generally to achieve any organisational objective [95].

It is now known that brands are characterised by a symbolic meaning that allows consumers to make better decisions in the purchase process and subsequent use of a service or product [96]. In this sense, brand awareness is the most important dimension of brand equity, as it influences brand preference and is capable of conditioning decision-making when purchasing a product [97], [98] as consumers choose brands they know [99]. In the initial stages of the creation of a new brand, as is the case of the present study, where recently-created micro-learning-platforms are examined, brand awareness is very important, also being the measurement most-used by marketing managers [38], as brand awareness is known to influence the purchase decision process by influencing the perception of the brand and determining which set of brands the consumer should consider [98]. Other advantages of brand awareness are decreased price sensitivity, reduced search for alternatives, and enhanced value judgments behaviour. [100].

Regarding its conceptualisation, brand awareness was initially defined as the consumers' ability to identify or recognise the brand [101] to which Keller added the need for recall [102], so it could now be said that brand awareness is conceptualised as the strength of a brand's presence in consumers' minds [78], [103], which results in the increased likelihood that products and services associated with a brand will be purchased for the first time or on successive occasions [102]. Brand awareness continues to be one of the fundamental factors for measuring brand equity, as excellent brand awareness could lead the user to consider only one brand for subsequent purchase [104], [105], and is of particular importance in high-involvement products, such as the education sector [106], as having a good brand equity, and specifically good brand awareness, correlated with brand market performance [107].

In the case of educational institutions, and in particular MOOC courses, brand awareness has become increasingly important [70] as it should not be forgotten that the number of courses and platforms has now increased substantially and it is critical that, for a student to show interest and acceptance in a MOOC course, it is linked to a wellknown educational brand [37], especially if it is the first time they are going to study in that institution [108]. MOOC courses associated with brands of prestigious institutions are not only automatically recognised as prestigious [37], [96], but also, thanks to brand awareness, achieve student satisfaction [109], create competitive advantage [110] and improve university performance [111], [112].

Regarding the antecedents of brand awareness, some previous research has shown that SMM, albeit in different intensity [54], influences brand awareness [93] and equity in general, including brand awareness [113]. Another possible antecedent of brand 
awareness is Customer Brand Engagement (CBE) as proposed by Algharabat et al. [114] and Kumar [115].

In the specific case of the education sector, it is known that universities have now started to improve their branding and social media strategies [116] in order to build strong brands [50] and engage their stakeholders and act to attract new students [117], [118] by improving brand loyalty, brand support [119] and generating brand awareness [95]. Therefore, the following hypotheses can be proposed:

H2 - SMM impacts on the brand awareness (BA) of micro-learning-platform students

H3 - CBE impacts on the brand awareness (BA) of micro-learning-platform students

At the same time, previous research has shown that $\mathrm{CBE}$ can act as a mediator between SMM and BA, as proposed by Bruhn et al. [71] and Chokpitakkul \& Anantachart [120], or between SMM and brand equity as confirmed by Chiang et al. [121]. In this sense it is likely that this mediating effect also occurs in the micro-learning platform sector, and therefore the following hypothesis is proposed:

$\mathrm{H} 4-\mathrm{CBE}$ is a mediator between SMM and BA in micro-learning platform students

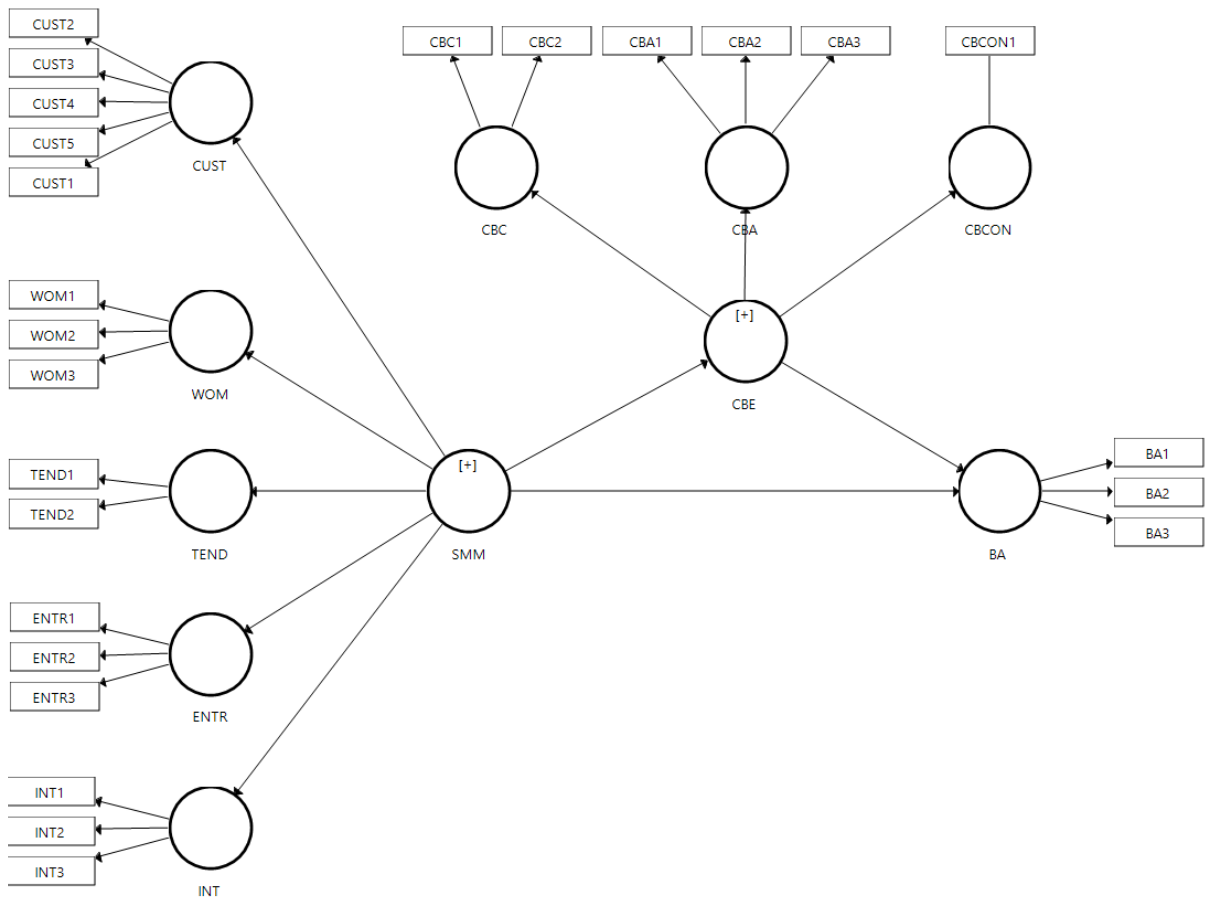

Fig. 1. Research Model

\section{Methodology}

As the research model includes casual relationships, the design followed explanatory research. An online survey was used to collect the data for evaluating scales, as it is 
cheaper, more effective, reaches further and guarantees the anonymity of study participants [122]. The study population consisted of students taking courses on micro-learning platforms in Peru and at the same time actively using social networks.

For the design of the instrument, recommendations to counteract "self-generated validity" were followed by carefully ordering the questions in the survey, using terminology and language that respondents found easy to understand [123]. The sample consisted of 220 respondents from the study population, equally divided between male and female, mostly university students who also study micro-learning courses in Crehana, Domestika and Netzun Plus (See Table 1).

Table 1. Sample profile

\begin{tabular}{|l|c|c|}
\hline \multicolumn{2}{|c|}{ Frequency } & $\%$ \\
\hline Gender & 102 & $46 \%$ \\
\hline Men & 118 & $54 \%$ \\
\hline Women & Education level \\
\hline \multicolumn{3}{|c|}{} \\
\hline Postgraduate studies & 37 & $17 \%$ \\
\hline Primary-Secondary school & 174 & $79 \%$ \\
\hline Technical-Higher Studies & 9 & $4 \%$ \\
\hline Occupation & 21 & $14 \%$ \\
\hline Unemployed & 59 & $22 \%$ \\
\hline Entrepreneur & 29 & $12 \%$ \\
\hline Independent Worker & 102 & $48 \%$ \\
\hline Employee & 100 & $46 \%$ \\
\hline Student & 47 & $22 \%$ \\
\hline Micro-learning platforms & 41 & $18 \%$ \\
\hline Crehana & 32 & $14 \%$ \\
\hline Domestika & \multicolumn{2}{|c|}{} \\
\hline Netzun Plus & \multicolumn{2}{|c|}{} \\
\hline Other & \multicolumn{2}{|c|}{} \\
\hline
\end{tabular}

For the measurement scales of the study constructs SMM, BCE and BA, scales that other authors had already tested in previous literature were adapted to the study context. All items of the instrument were set on a Likert scale with ratings from 1-7, where 1 denoted strongly disagree and 7 denoted strongly agree. The multidimensional scale of Cheung et al. [54] was used to measure SMM. The first dimension, customisation (CUST), consisted of five items, the second, e-WOM (WOM), consisted of three items, the third, trends (TEND), consisted of two items, entertainment (ENTR) consisted of three items and interaction (INT) consisted of three items. For CBE, the scale of Leckie et al. [124] was adapted. CBE was also measured in a multidimensional way through cognitive brand engagement (CBA), affective brand engagement (CBC) and behavioural brand engagement $(\mathrm{CBCON})$. The first two dimensions consisted of three items each, while behavioural brand engagement was measured using only one item. Finally, 
four items were used for brand awareness (BA), which were adapted from Godey et al. [55] and Langaro et al. [82].

The validation of the model was done through Partial Least Squares (PLS), as developed by Wold [125], using the statistical program Smart-PLS 3.3.2 created by Ringle, Wende, \& Becker [126] which allows the estimation of structural models with unobservable variables [127], [128]. Taking into account that the CBE and SMM are multidimensional reflective variables, the validation of the model was done in three steps. The measurement model of lower-order reflective constructs, the measurement model of higher-order reflective constructs and Structural model assessment [129].

\section{$4 \quad$ Results}

The use de higher-order constructs, also known as multidimensional constructs or hierarchical latent variable models or second-order constructs have become popular in recent years because they allow increasingly complex research models to be developed and studied [130]. Due to the presence of second-order reflective constructs, CBE and SMM, the embedded two-stage approach of hierarchical models with Mode A was adopted [129].

The first step followed in the embedded two-stage approach was checks for the measurement model of lower-order reflective constructs [131], for which Cronbach's Alpha, Composite reliability and the Convergent validity (AVE) were calculated. As can be seen in table 2, both Cronbach's Alpha and composite reliability values were above 0.7 [132], [133] while AVE values were above 0.5 [128], [134], [135]; therefore it can be stated that the lower-order reflective constructs comply with the internal consistency reliability, the composite reliability and the convergent validity.

Although discriminant validity was initially measured with the Fornell-Larcker model, recently its inadequate ability to detect discriminant validity has been shown [135]-[137]. In this sense, the discriminant validity of lower-order reflective constructs was evaluated using the HTMT (Heterotrait- Monotrait) ratio. As can be seen from table 3, all values are below 0.9 [138], from which it can be concluded that no issue of discriminant validity was found in the lower-order formative model.

Once the measurement model of lower-order reflective constructs had been checked, the second step was the measurement model of high-order reflective constructs for which the Internal consistency reliability was calculated, plus the composite reliability, the convergent validity and the Discriminant validity [129]. Table 4 summarises the results of Cronbach's Alpha, the Composite reliability, and the convergent validity. The Cronbach's Alpha Composite reliability shows values over 0.7 [133] and therefore the internal consistency reliability in the measurement model of high-order reflective constructs could be confirmed. In the case of AVE its levels were above 0.5 [134], [135] thus proving the convergent validity. 
Paper-Micro-learning Platforms Brand Awareness Using Social-media Marketing and Customer...

Table 2. Reliability and validity measures of lower-order formative constructs

\begin{tabular}{|c|c|c|c|c|c|}
\hline Construct & Items & Loadings & Cronbach's Alpha & Composite Reliability & $\begin{array}{l}\text { Average Variance } \\
\text { Extracted (AVE) }\end{array}$ \\
\hline \multirow[t]{3}{*}{$\mathrm{BA}$} & BA1 & 0,87 & 0,80 & 0,88 & 0,72 \\
\hline & BA2 & 0,81 & & & \\
\hline & BA3 & 0,86 & & & \\
\hline \multirow[t]{3}{*}{ CBA } & CBA1 & 0,94 & 0,94 & 0,96 & 0,89 \\
\hline & CBA2 & 0,97 & & & \\
\hline & CBA3 & 0,93 & & & \\
\hline \multirow[t]{2}{*}{$\mathrm{CBC}$} & CBC1 & 0,97 & 0,93 & 0,97 & 0,94 \\
\hline & $\mathrm{CBC} 2$ & 0,97 & & & \\
\hline $\mathrm{CBCON}$ & CBCON1 & 1,00 & & & \\
\hline \multirow[t]{5}{*}{ CUST } & CUST1 & 0,86 & 0,91 & 0,94 & 0,74 \\
\hline & CUST2 & 0,89 & & & \\
\hline & CUST3 & 0,86 & & & \\
\hline & CUST4 & 0,86 & & & \\
\hline & CUST5 & 0,85 & & & \\
\hline \multirow[t]{3}{*}{ ENTR } & ENTR1 & 0,87 & 0,85 & 0,91 & 0,77 \\
\hline & ENTR2 & 0,88 & & & \\
\hline & ENTR3 & 0,89 & & & \\
\hline \multirow[t]{3}{*}{ INT } & INT1 & 0,93 & 0,91 & 0,95 & 0,85 \\
\hline & INT2 & 0,93 & & & \\
\hline & INT3 & 0,91 & & & \\
\hline \multirow[t]{2}{*}{ TEND } & TEND1 & 0,88 & 0,75 & 0,89 & 0,80 \\
\hline & TEND2 & 0,90 & & & \\
\hline \multirow[t]{3}{*}{ WOM } & WOM1 & 0,83 & 0,87 & 0,92 & 0,79 \\
\hline & WOM2 & 0,93 & & & \\
\hline & WOM3 & 0,90 & & & \\
\hline
\end{tabular}

Table 3. Discriminant Validity of lower-order reflective constructs - HTMT

\begin{tabular}{|l|c|c|c|c|c|c|c|c|c|}
\hline & BA & CBA & CBC & CBCON & CUST & ENTR & INT & TEND & WOM \\
\hline BA & & & & & & & & & \\
\hline CBA & 0,85 & & & & & & & & \\
\hline CBC & 0,80 & 0,84 & & & & & & & \\
\hline CBCON & 0,75 & 0,74 & 0,67 & & & & & & \\
\hline CUST & 0,36 & 0,20 & 0,15 & 0,14 & & & & & \\
\hline ENTR & 0,48 & 0,56 & 0,44 & 0,40 & 0,47 & & & & \\
\hline INT & 0,59 & 0,55 & 0,56 & 0,54 & 0,39 & 0,63 & & & \\
\hline TEND & 0,44 & 0,42 & 0,33 & 0,35 & 0,53 & 0,79 & 0,64 & & \\
\hline WOM & 0,20 & 0,26 & 0,19 & 0,14 & 0,45 & 0,50 & 0,19 & 0,64 & \\
\hline
\end{tabular}


Paper-Micro-learning Platforms Brand Awareness Using Social-media Marketing and Customer...

Table 4. Reliability and validity measures of high-order formative constructs

\begin{tabular}{|l|c|c|c|}
\hline \multicolumn{1}{|c|}{ Construct } & Cronbach's alpha & Composite reliability & Average variance Extracted (AVE) \\
\hline CBE & 0,88 & 0,93 & 0,81 \\
\hline SMM & 0,80 & 0,86 & 0,55 \\
\hline
\end{tabular}

To complete the second stage, discriminant validity of lower-order reflective constructs was calculated using the HTMT (Heterotrait- Monotrait ratio) of the high-order formative constructs. Table 5 shows that all values are under 0.9 , and as a consequence no issue of discriminant validity was found in the high-order formative model.

Table 5. Discriminant Validity of high-order reflective constructs - HTMT

\begin{tabular}{|l|c|c|c|}
\hline & BA & CBE & SMM \\
\hline BA & & & \\
\hline CBE & 0,83 & & \\
\hline SMM & 0,52 & 0,56 & \\
\hline
\end{tabular}

After the Measurement model of low and higher-order formative constructs, the Structural model assessment was followed [129] using bootstrapping with 5000 subsamples of $\mathrm{p}<0.05$. Coefficient of determination $\left(\mathrm{R}^{2}\right)$, effect size $\left(\mathrm{f}^{2}\right)$, and predictive relevance $\left(\mathrm{Q}^{2}\right)$ were evaluated.

In the case of $\mathrm{R}^{2}$, as seen in table 7 , the $\mathrm{CBE}$ has a value of 0.28 , indicating that $28 \%$ of variation of $\mathrm{CBE}$ is accounted for by SMM. Also, BA with an $\mathrm{R}^{2}$ of 0.63 indicates that $63 \%$ of its variations are explained by CBE and SMM.

To measure the true impact of an independent variable on the dependent variable effect size $\left(\mathrm{f}^{2}\right)$ was used. Their values can be considered low if they are below 0.02 , medium if below 0.15 or high if above 0.35 [139]. Table 6 shows that CBE has a large effect size on BA (1.00), similarly SMM has a large effect size on CBE, since in both cases $\mathrm{f}^{2}$ is over 0.3. Meanwhile SMM has low effect size over BA since $\mathrm{f}^{2}$ is 0.03 [139], [140].

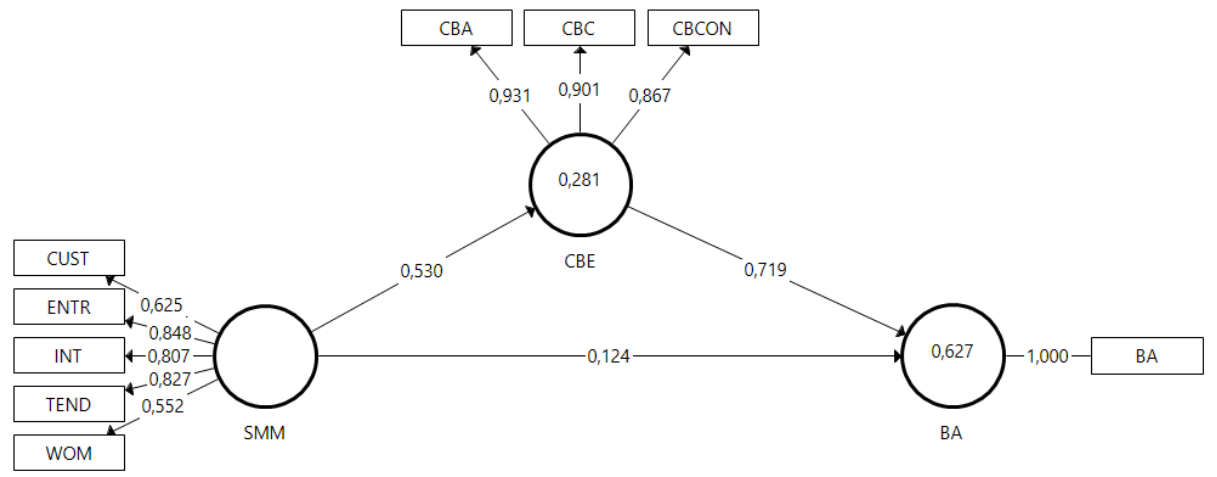

Fig. 2. Step two of embedded two-stage approach 
Table 6. Hypothesis testing

\begin{tabular}{|c|c|c|c|c|c|c|}
\hline \multicolumn{2}{|r|}{ Hypothesis } & Original Sample (O) & t-value & $\mathbf{f}^{2}$ & p Values & Supported \\
\hline $\mathrm{H} 3$ & $\mathrm{CBE}->\mathrm{BA}$ & 0,72 & 16,55 & 1,00 & 0,00 & Yes \\
\hline $\mathrm{H} 2$ & SMM -> BA & 0,50 & 10,59 & 0,03 & 0,00 & Yes \\
\hline H1 & SMM -> CBE & 0,53 & 11,70 & 0,39 & 0,00 & Yes \\
\hline H4 & $\mathrm{SMM}->\mathrm{CBE}->\mathrm{BA}$ & 0,39 & 8,35 & & 0,00 & Yes \\
\hline \multicolumn{7}{|c|}{ Total Indirect Effects } \\
\hline & SMM -> BA & 0,38 & 8,35 & & 0,00 & \\
\hline \multicolumn{7}{|c|}{ Specific Indirect Effects } \\
\hline & $\mathrm{SMM}->\mathrm{CBE}->\mathrm{BA}$ & 0,39 & 8,35 & & 0,00 & \\
\hline
\end{tabular}

Table 7. Structural model assessment

\begin{tabular}{|l|c|c|}
\hline \multicolumn{1}{|c|}{ Construct } & $\mathbf{R}^{\mathbf{2}}$ & $\mathbf{Q}^{\mathbf{2}}$ \\
\hline BA & 0,63 & 0,62 \\
\hline CBE & 0,28 & 0,22 \\
\hline
\end{tabular}

Moreover, a Blindfolding process with an omission distance of 7 was run for investigating the out-of-sample predictive relevance through $\mathrm{Q}^{2}$. The results (see table 8 ) show that $\mathrm{Q}^{2}$ values are 0.62 for BA and 0.22 for CBE. In the first case, BA shows a high predictive relevance, while CBE has a low predictive relevance [128], [134].

Finally, the hypotheses were evaluated. The first three hypotheses mediate the direct relationship between SMM - CBE (H1), CBE -BA (H2), and SMM and BA (H3). As can be seen in table 7, SMM was found to have a significance on CBE with a path coefficient of 0.53 and a sig $<0.05$, which allows the acceptance of $\mathrm{H} 1$. With respect to $\mathrm{H} 3$, with a path coefficient between $\mathrm{CBE}$ and BA of 0.72 , it can also be stated that $\mathrm{H} 3$ is accepted with sig<0.05. The path coefficient between SMM and BA was 0.5, and therefore $\mathrm{H} 2$ could also be confirmed, with sig<0.05.

The mediation relationship that CBE exercises between SMM and BA was also assessed. In this case, as can be seen in table 6 , there is significance both in the case of the direct relationship between SMM and BA, and in the indirect relationship through the mediator of CBE. Therefore, there is a partial mediation [141].

\section{Conclusions}

The results of the present research are a relevant contribution to the study of the behaviour of learners on micro-learning platforms. In this sense, the first contribution focuses on the expansion of knowledge on the relationship between SMM, CBE and $\mathrm{BA}$ in the educational sector in general, but mainly in micro-learning platforms. While it is true that these variables had been studied previously in other contexts [54], [55], [61], [142], their study in the educational environment was practically non-existent or had been studied in isolation. Furthermore, it should be noted that this study has examined SMM and CBE as multidimensional reflective variables through the application 
of the embedded two-stage approach of hierarchical model, which has allowed a more correct evaluation of these constructs.

The results have enabled verification that the SMM generated by micro-learning platforms contributes to both $\mathrm{CBE}$ and $\mathrm{BA}$ generation. In the case of the relationship between SMM and CBE, the results of this study reinforce the findings of Barreda et al. [93]; Beckers et al. [90]; Cheung et al. [54]; Harmeling et al., [91]; Venkatesan [92], which in contexts other than education, had already proven this relationship. It was also found that SMM contributes to the generation of BA, which reaffirms the findings of Algharabat et al. [114], Kumar [115], Pharr [116] and Pinar et al.[50].

With regard to the relationship between $\mathrm{CBE}$ and the BA of micro-learning platforms, the results of this study are consistent with the previous literature that affirmed that $\mathrm{CBE}$ has a strong and positive impact on BA, being fundamental to its construction [54], [62], [143], [144]. In this sense, the findings of this study have gone beyond the direct relationship between SMM and BA by enabling proof that CBE is not only important for generating BA, but also fundamental for SMM to have the desired effect of generating BA in students on micro-learning platforms, which is a significant contribution to previous research, such as that of Seo \& Park [142].

From a practical point of view, this study allows micro-learning platforms to understand how their SMM activities contribute to the generation of BA in their course students, which should make their students less price-sensitive and less likely to search for alternatives [100]. Considering that social media is an important resource to communicate with students [56], its use is critical not only to achieve communication and relationships [2], [34], but also to make their platforms known, so it is very important to understand that while SMM achieves general BA directly, its impact is substantially greater when it is done through CBE. This means that contrary to what one might think, micro-learning platforms, when planning their branding strategies, should not only think about SMM, but should also focus on $\mathrm{CBE}$ as it plays a fundamental role in building BA.

\section{$6 \quad$ Limitations and further research}

This study presents certain limitations. Firstly, it is worth mentioning that the research was carried out only in Peru, so it would be advisable to replicate this research in other countries and cultural realities in order to expand and globalise the findings on micro-learning platforms and their relationship with SMM, CBE and brand awareness.

On the other hand, although CBE is generated through SMM, some previous studies have suggested that BA is better generated through traditional platforms such as TV, radio, or outdoor advertising; so it would be useful to evaluate how these platforms influence $\mathrm{CBE}$ and brand awareness of educational institutions in general, and microlearning platforms in particular.

Also, previous studies have suggested that CBE may be not only an antecedent of BA, but also the consequence of BA [85], [145], [146] so a cross-cutting study is proposed, to assess whether BA can generate CBE in the education sector. Also, as is known, brand awareness is part of brand equity, so including all dimensions of brand 
equity in future studies would improve knowledge about brand management of microlearning platforms.

Finally, including the study of micro-credentials is suggested, as their occurrence is likely to condition the likelihood of learners showing interest in micro-learning platform courses [147] as well as learners showing CBE or BA.

In other sectors it has been shown that brand equity, and therefore brand awareness, generates $\mathrm{CBE}$, for example the luxury brand sector in social networks [85], or in the tourism sector brand awareness has a CBE effect [145], [146], so it would be appropriate to evaluate whether $\mathrm{CBE}$ is not only an antecedent of BA but also a consequence of CBE.

\section{$7 \quad$ References}

[1] A. Y. Lozovoy and E. K. Zashchitina, "Online Education: Pros and Cons," Proc. 2019 IEEE Int. Conf. Qual. Manag. Transp. Inf. Secur. Inf. Technol. IT QM IS 2019, pp. 631-633, 2019, https://doi.org/10.1109/itqmis.2019.8928455.

[2] C. Du Plessis, "The role of content marketing in social media content communities," SA J. Inf. Manag., vol. 19, no. 1, pp. 1-7, 2017, https://doi.org/10.4102/sajim.v19i1.866.

[3] L. Yen Chaw and C. Meng Tang, "Improving Learners' Inclination to Complete Online Courses: Motivation and Engagement Factors," 2018.

[4] L. Breslow, D. Pritchard, J. DeBoer, G. Stump, A. Ho, and D. Seaton, "Studying learning in the worldwide classroom: Research into edX's first MOOC," Res. \&amp; Pract. Assess., vol. 8, no. 13-25, 2013.

[5] D. Gamage, I. Perera, and S. Fernando, "Exploring MOOC User Behaviors Beyond Platforms," Int. J. Emerg. Technol. Learn., vol. 15, no. 08, pp. 161-179, Apr. 2020, https:// doi.org/10.3991/ijet.v15i08.12493.

[6] T. R. Liyanagunawardena, A. A. Adams, and S. A. Williams, "MOOCs: A systematic study of the published literature 2008-2012," Int. Rev. Res. Open Distance Learn., vol. 14, no. 3, pp. 202-227, 2013, https://doi.org/10.19173/irrodl.v14i3.1455.

[7] E. C. D. Laurie, J. H. D. Kim, P. W. J. José, and L. M. Rob, "Predicting and resolving noncompletion in higher (online) education - A literature review," Educ. Res. Rev., vol. 29, no. December 2019, p. 100313, 2020, https://doi.org/10.1016/j.edurev.2020.100313.

[8] F. Li, J. Qi, G. Wang, and X. Wang, "PAPER TRADITIONAL CLASSROOM VS ELEARNING IN HIGHER EDUCATION: DIFFERENCE BETWEEN STUDENTS' BEHAVIORAL. Traditional Classroom VS E-learning in Higher Education: Difference between Students' Behav-ioral Engagement," Int. J. Emerg. Technol. Learn., vol. 9, no. 2, pp. 48-51, Mar. 2014, https://doi.org/10.3991/ijet.v9i2.3268.

[9] O. Kitchakarn, "USING BLOGS TO IMPROVE STUDENTS' SUMMARY WRITING ABILITIES," Turkish Online J. Distance Educ., vol. 13, no. 4, pp. 209-2019, 2012, Accessed: 20-Feb-2021. [Online]. Available: www.blogger.com.

[10] Z. A. Shana and E. S. Abulibdeh, "PAPER ENGAGING STUDENTS THROUGH BLOGS: USING BLOGS TO BOOST A COURSE EXPERIENCE Engaging Students through Blogs: Using Blogs to Boost a Course Experience," Int. J. Emerg. Technol. Learn., vol. 10, no. 1, pp. 30-38, Feb. 2015, https://doi.org/10.3991/ijet.v10i1.4240.

[11] D. Kamilali and C. Sofianopoulou, "MICROLEARNING AS INNOVATIVE PEDAGOGY FOR MOBILE LEARNING IN MOOCS," in International Conference on Mobile Learning, 2015. 
[12] T. Eriksson, T. Adawi, and C. Stöhr, “'Time is the bottleneck': a qualitative study exploring why learners drop out of MOOCs," J. Comput. High. Educ., vol. 29, no. 1, pp. 133-146, Apr. 2017, https://doi.org/10.1007/s12528-016-9127-8.

[13] P. J. Guo, J. Kim, and R. Rubin, "How video production affects student engagement: An empirical study of MOOC videos," in L@S 2014 - Proceedings of the 1st ACM Conference on Learning at Scale, 2014, pp. 41-50, https://doi.org/10.1145/2556325.2566239.

[14] R. F. Kizilcec, C. Piech, and E. Schneider, Deconstructing Disengagement: Analyzing Learner Subpopulations in Massive Open Online Courses. 2013. https://doi.org/10.1145/ 2460296.2460330 .

[15] C. John, T. Staubitz, and C. Meinel, "Took a MOOC. Got a Certificate. What now?," in Proceedings - Frontiers in Education Conference, FIE, 2019, vol. 2019-October, pp. 1-9, https://doi.org/10.1109/fie43999.2019.9028698.

[16] K. Eikenberry, "New training strategies for a new day," Strateg. HR Rev., vol. 16, no. 6, pp. 261-266, Nov. 2017, https://doi.org/10.1108/shr-08-2017-0060.

[17] G. Sun, T. Cui, W. Guo, G. Beydoun, D. Xu, and J. Shen, "Micro learning adaptation in MOOC: A software as a service and a personalized learner model," in Lecture Notes in Computer Science (including subseries Lecture Notes in Artificial Intelligence and Lecture Notes in Bioinformatics), 2015, vol. 9412, pp. 174-184, https://doi.org/10.1007/978-3-31925515-6 16.

[18] K. Leong, A. Sung, D. Au, and C. Blanchard, "A review of the trend of microlearning," $J$. Work. Manag., vol. ahead-of-print, no. ahead-of-print, Dec. 2020, doi: 10.1108/jwam-102020-0044.

[19] T. Javorcik and R. Polasek, "Transformation of e-learning into microlearning: New approach to course design," in AIP Conference Proceedings, 2019, vol. 2116, no. 1, p. 060016, https://doi.org/10.1063/1.5114051.

[20] J. S. Beaudin, S. S. Intille, E. M. Tapia, R. Rockinson, and M. E. Morris, "Context-sensitive microlearning of foreign language vocabulary on a mobile device," in Lecture Notes in Computer Science (including subseries Lecture Notes in Artificial Intelligence and Lecture Notes in Bioinformatics), 2007, vol. 4794 LNCS, pp. 55-72, https://doi.org/10.1007/978-3540-76652-0 4.

[21] D. Kovachev, Y. Cao, R. Klamma, and M. Jarke, "Learn-as-you-go: New ways of cloudbased micro-learning for the mobile web," in Lecture Notes in Computer Science (including subseries Lecture Notes in Artificial Intelligence and Lecture Notes in Bioinformatics), 2011, vol. 7048 LNCS, pp. 51-61, https://doi.org/10.1007/978-3-642-25813-8 6.

[22] C. Wang, M. Bakhet, D. Roberts, S. Gnani, and A. El-Osta, "The efficacy of microlearning in improving self-care capability: a systematic review of the literature," Public Health, vol. 186. Elsevier B.V., pp. 286-296, 01-Sep-2020, https://doi.org/10.1016/j.puhe.2020.07.007.

[23] T. Javorcik and R. Polasek, "The Basis for Choosing Microlearning Within the Terms of ELearning in the Context of Student Preferences," in ICETA 2018 - 16th IEEE International Conference on Emerging eLearning Technologies and Applications, Proceedings, 2018, pp. 237-244, https://doi.org/10.1109/iceta.2018.8572183.

[24] S. Chai-Arayalert and S. Puttinaovarat, "Designing Mangrove Ecology Self-Learning Application Based on a Micro-Learning Approach Designing Mangrove Ecology SelfLearning Application Based on a Micro-Learning Approach,” Int. J. Emerg. Technol. Learn., vol. 15, no. 11, pp. 29-41, Jun. 2020, https://doi.org/10.3991/ijet.v15i11.12585.

[25] R. P. Díaz Redondo, A. Ktena, N. Kunicina, A. Zabasta, A. Patlins, and D. Enea Mele, "Advanced practices: micro learning, practice oriented teaching and gamified learning," in Conference: 2020 IEEE 61th International Scientific Conference on Power and Electrical Engineering, 2020, https://doi.org/10.1109/rtucon51174.2020.9316555. 
[26] J. Salinas and V. I. Marín, "Pasado, presente y futuro del microlearning como estrategia para el desarrollo profesional," Campus Virtuales, vol. III, no. 2, pp. 46-61, Aug. 2014, Accessed: 22-Feb-2021. [Online]. Available: www.revistacampusvirtuales.es.

[27] R. Elliott, J. Clayton, and J. Iwata, "Exploring the use of micro-credentialing and digital badges in learning environments to encourage motivation to learn and achieve," in Proceedings of ASCILITE 2014 - Annual Conference of the Australian Society for Computers in Tertiary Education, 2014, pp. 703-707.

[28] R. P. Díaz Redondo, M. Caeiro Rodríguez, J. J. López Escobar, and A. Fernández Vilas, "Integrating micro-learning content in traditional e-learning platforms," Multimed. Tools Appl., vol. 80, no. 2, pp. 3121-3151, Jan. 2021, https://doi.org/10.1007/s11042-020-09523z.

[29] M. J. Dolasinski and J. Reynolds, "Microlearning: A New Learning Model," J. Hosp. Tour. Res., vol. 44, no. 3, pp. 551-561, Mar. 2020, https://doi.org/10.1177/1096348020901579.

[30] C. P. Baloco Navarro and C. T. Ricardo Barreto, "LOS MOOC EN LA EDUCACIÓN SUPERIOR," Saber, Cienc. y Lib., vol. 13, no. 2, pp. 250-260, Dec. 2018, https://doi.org/10. 18041/2382-3240/saber.2018v13n2.4639.

[31] Global Edtech, "Peruvian EdTech company Crehana experiencing rapid growth - Global EdTech,” 28-May-2020. https://www.global-edtech.com/peruvian-edtech-companycrehana-experiencing-rapid-growth/ (accessed Mar. 10, 2021). https://doi.org/10.4135/978 1483393377.n3.

[32] Global Edtech, "Latam EdTech firms plan future growth - Global EdTech," 03-Aug-2020. https://www.global-edtech.com/latam-edtech-firms-plan-future-growth/ (accessed Mar. 10, 2021). https://doi.org/10.4135/9781483393377.n3.

[33] F. Jin, A. Wu, and L. Hitt, "Social Is the New Financial: How Startup Social Media Activity Influences Funding Outcomes," Acad. Manag. Proc., vol. 2017, no. 1, p. 13329, 2017, https: //doi.org/10.5465/ambpp.2017.13329abstract.

[34] D. Creevey, E. Kidney, and G. Mehta, "From dreaming to believing: A review of consumer engagement behaviours with brands' social media content across the holiday travel process," J. Travel Tour. Mark., vol. 36, no. 6, pp. 679-691, 2019, https://doi.org/10.1080/10548408. 2019.1624242.

[35] A. Ray, P. K. Bala, S. Chakraborty, and S. A. Dasgupta, "Exploring the impact of different factors on brand equity and intention to take up online courses from e-Learning platforms," J. Retail. Consum. Serv., vol. 59, p. 102351, Mar. 2021, https://doi.org/10.1016/j.jretconser .2020 .102351 .

[36] E. Costello, J. Brunton, M. Brown, and L. Daly, "In MOOCs we Trust: Learner Perceptions of MOOC Quality via Trust and Credibility," Int. J. Emerg. Technol. Learn., vol. 13, no. 06, pp. 214-222, May 2018, https://doi.org/10.3991/ijet.v13i06.8447.

[37] K. M. Alraimi, H. Zo, and A. P. Ciganek, "Understanding the MOOCs continuance: The role of openness and reputation," Comput. Educ., vol. 80, pp. 28-38, Jan. 2015, https://doi. org/10.1016/j.compedu.2014.08.006.

[38] J. Romaniuk, S. Wight, and M. Faulkner, "Brand awareness: revisiting an old metric for a new world," J. Prod. Brand Manag., vol. 26, no. 5, pp. 469-476, 2017, https://doi.org/ 10.1108/jpbm-06-2016-1242.

[39] S. L. Taylor and R. M. Cosenza, "Profiling later aged female teens: Mall shopping behavior and clothing choice," Journal of Consumer Marketing, vol. 19, no. 5. MCB UP Ltd, pp. 393-408, 2002, https://doi.org/10.1108/07363760210437623.

[40] J. U. Islam, Z. Rahman, and L. D. Hollebeek, "Internet Research Consumer engagement in online brand communities: A solicitation of congruity theory Article information," Emerald Insight, vol. 28, no. 1, 2018. https://doi.org/10.1108/intr-09-2016-0279. 
Paper-Micro-learning Platforms Brand Awareness Using Social-media Marketing and Customer...

[41] C.-H. Lien, Y. Cao, and X. Zhou, "Service quality, satisfaction, stickiness, and usage intentions: An exploratory evaluation in the context of WeChat services," Comput. Human Behav., vol. 68, pp. 403-410, Mar. 2017, https://doi.org/10.1016/j.chb.2016.11.061.

[42] V. Kumar and A. Pansari, "Competitive Advantage thourgh Engagement," J. Mark. Res., pp. $0-51,2015$.

[43] J. L.-H. Bowden, "The Process of Customer Engagement: A Conceptual Framework," J. Mark. Theory Pract., vol. 17, no. 1, pp. 63-74, Jan. 2009, https://doi.org/10.2753/MTP10696679170105.

[44] R. J. Brodie, A. Ilic, B. Juric, and L. Hollebeek, "Consumer engagement in a virtual brand community: An exploratory analysis,” J. Bus. Res., vol. 66, no. 1, pp. 105-114, 2013, https:// doi.org/10.1016/j.jbusres.2011.07.029.

[45] L. Dessart, C. Veloutsou, and A. Morgan-Thomas, "Consumer engagement in online brand communities: A social media perspective," J. Prod. Brand Manag., vol. 24, no. 1, pp. 28 42, 2015, https://doi.org/10.1108/jpbm-06-2014-0635.

[46] A. Mollen and H. Wilson, "Engagement, telepresence and interactivity in online consumer experience: Reconciling scholastic and managerial perspectives," J. Bus. Res., vol. 63, no. 9-10, pp. 919-925, 2010, https://doi.org/10.1016/j.jbusres.2009.05.014.

[47] L. Blasco-Arcas, I. Buil, B. Hernández-Ortega, and F. J. Sese, "Using clickers in class. the role of interactivity, active collaborative learning and engagement in learning performance," Comput. Educ., vol. 62, pp. 102-110, Mar. 2013, https://doi.org/10.1016/j.compedu.2012. 10.019 .

[48] J. A. Fredricks, P. C. Blumenfeld, and A. H. Paris, "School engagement: Potential of the concept, state of the evidence," Review of Educational Research, vol. 74, no. 1. American Educational Research Association, pp. 59-109, 2004, https://doi.org/10.3102/00346543 074001059.

[49] M. Man, M. Hafriz, N. Azhan, W. Mohd, A. Fazamin, and W. Hamzah, "Conceptual Model for Profiling Student Behavior Experience in e-Learning," Int. J. Emerg. Technol. Learn., vol. 14, no. 21, pp. 163-175, Nov. 2019, https://doi.org/10.3991/ijet.v14i21.10936.

[50] M. Pinar, T. Girard, and C. Basfirinci, "Examining the relationship between brand equity dimensions and university brand equity: An empirical study in Turkey," Int. J. Educ. Manag., vol. 34, no. 7, pp. 1119-1141, Mar. 2020, https://doi.org/10.1108/ijem-08-2019$\underline{0313}$.

[51] A. Ray, P. K. Bala, and S. A. Dasgupta, "Psychological Analytics Based Technology Adoption Model for Effective Educational Marketing," Springer, Cham, 2020, pp. 163-174.

[52] K. Leong, A. Sung, D. Au, and C. Blanchard, "A review of the trend of microlearning," $J$. Work. Manag., vol. ahead-of-print, no. ahead-of-print, Dec. 2020, https://doi.org/10.1108/ jwam-10-2020-0044.

[53] H. Prabowo and T. Sriwidadi, "The Effect of Marketing Mix toward Brand Equity at Higher Education Institutions: A Case Study in BINUS Online Learning Jakarta," 2019.

[54] M. L. Cheung, G. Pires, and P. J. Rosenberger, "The influence of perceived social media marketing elements on consumer-brand engagement and brand knowledge," Asia Pacific J. Mark. Logist., vol. 32, no. 3, pp. 695-720, 2020, https://doi.org/10.1108/apjml-04-20190262.

[55] B. Godey et al., "Social media marketing efforts of luxury brands: Influence on brand equity and consumer behavior," J. Bus. Res., vol. 69, no. 12, pp. 5833-5841, 2016, https://doi.org /10.1016/j.jbusres.2016.04.181.

[56] E. Lidia Alexa, M. Alexa, and C. Maria Stoica, "The Use of Online Marketing and Social Media in Higher Education Institutions in Romania," vol. 2012, 2012, https://oi.org/10. $\underline{5171 / 2012.721221 .}$. 
[57] S. M. Mudambi, D. Schuff, and D. Schuff, "Quarterly What Makes a Helpful Online Reviews A Study of Customer Review? on Amazon . com1," vol. 34, no. 1, pp. 185-200, 2016. https://doi.org/10.2307/20721420.

[58] T. Hennig-Thurau, K. P. Gwinner, and D. D. Gremler, "Understanding Relationship Marketing Outcomes: An Integration of Relational Benefits and Relationship Quality," $J$. Serv. Res., 2002, https://doi.org/10.1177/1094670502004003006.

[59] V. Koubova and A. A. Buchko, "Social eWOM: Does it Affect the Brand Attitude and Purchase Intention of Brands?," Manag. Res. Rev., vol. 36, no. 7, pp. 700-719, 2017.

[60] M. Yadav and Z. Rahman, "Measuring consumer perception of social media marketing activities in e-commerce industry: Scale development \& validation," Telemat. Informatics, vol. 34, no. 7, pp. 1294-1307, 2017, https://doi.org/10.1016/j.tele.2017.06.001.

[61] S. C. Chen and C. P. Lin, "Understanding the effect of social media marketing activities: The mediation of social identification, perceived value, and satisfaction," Technol. Forecast. Soc. Change, vol. 140, no. July 2018, pp. 22-32, 2019, https://doi.org/10.1016/j.techfore. 2018.11.025.

[62] A. J. Kim and E. Ko, "Do social media marketing activities enhance customer equity? An empirical study of luxury fashion brand," J. Bus. Res., vol. 65, no. 10, pp. 1480-1486, 2012, https://doi.org/10.1016/j.jbusres.2011.10.014.

[63] S. J. Mcmillan, "Gearing Up for Mobile Advertising : A Cross- Key Factors That Drive," Psychology, vol. 25, no. August 2008, pp. 756-768, 2013.

[64] T. J. Johnson and B. K. Kaye, "Site Effects: How Reliance on Social Media Influences Confidence in the Government and News Media," Soc. Sci. Comput. Rev., vol. 33, no. 2, pp. 127-144, 2015, https://doi.org/10.1177/0894439314537029.

[65] M. Abdulaziz Alsubhi, N. Sahari, and T. Siti Meriam Tengku Wook, "A Conceptual Engagement Framework for Gamified E-Learning Platform Activities," Int. J. Emerg. Technol. Learn., vol. 15, no. 22, pp. 4-23, Nov. 2020, https://doi.org/10.3991/ijet.v15i22. 15443.

[66] D. G. Muntinga, M. Moorman, and E. G. Smit, "Introducing COBRAs: Exploring motivations for Brand-Related social media use," Int. J. Advert., vol. 30, no. 1, pp. 37-41, 2011, https://doi.org/10.2501/ija-30-1-013-046.

[67] E. Fischer and A. R. Reuber, "Social interaction via new social media: (How) can interactions on Twitter affect effectual thinking and behavior?," J. Bus. Ventur., vol. 26, no. 1, pp. 1-18, 2011, https://doi.org/10.1016/j.jbusvent.2010.09.002.

[68] I. Y. Alyoussef, "Paper-An Empirical Investigation on Students' Acceptance of (SM) Use for Teaching and Learning An Empirical Investigation on Students' Acceptance of (SM) Use for Teaching and Learning," Int. J. Emerg. Technol. Learn., vol. 15, no. 04, pp. 158178, Feb. 2020, https://doi.org/10.3991/ijet.v15i04.11660.

[69] J. Ruiz-Palmero, D. López-Álvarez, E. Sánchez-Rivas, and J. Sánchez-Rodríguez, “An analysis of the profiles and the opinion of students enrolled on xMOOCs at the University of Malaga," Sustain., vol. 11, no. 24, Dec. 2019, https://doi.org/10.3390/su11246910.

[70] A. M. Kaplan and M. Haenlein, "Higher education and the digital revolution: About MOOCs, SPOCs, social media, and the Cookie Monster," Bus. Horiz., vol. 59, no. 4, pp. 441-450, Jul. 2016, https://doi.org/10.1016/j.bushor.2016.03.008.

[71] M. Bruhn, V. Schoenmueller, and D. B. Schäfer, "Are social media replacing traditional media in terms of brand equity creation?," Manag. Res. Rev., vol. 35, no. 9, pp. 770-790, Aug. 2012, https://doi.org/10.1108/01409171211255948.

[72] K. Y. Koay, D. L. T. Ong, K. L. Khoo, and H. J. Yeoh, "Perceived social media marketing activities and consumer-based brand equity: Testing a moderated mediation model," Asia 
Paper-Micro-learning Platforms Brand Awareness Using Social-media Marketing and Customer...

Pacific J. Mark. Logist., vol. 33, no. 1, pp. 53-72, Feb. 2020, https://doi.org/10.1108/apjml$\underline{07-2019-0453}$

[73] X. Yu and C. Yuan, "How consumers' brand experience in social media can improve brand perception and customer equity," Asia Pacific J. Mark. Logist., vol. 31, no. 5, pp. 12331251, Nov. 2019, https://doi.org/10.1108/apiml-01-2018-0034.

[74] L. W. Wong, G. W. H. Tan, J. J. Hew, K. B. Ooi, and L. Y. Leong, "Mobile social media marketing: a new marketing channel among digital natives in higher education?," J. Mark. High. Educ., 2020, https://doi.org/10.1080/08841241.2020.1834486.

[75] D. Lee, P. M. L. Ng, and S. Bogomolova, "The impact of university brand identification and eWOM behaviour on students' psychological well-being: a multi-group analysis among active and passive social media users," J. Mark. Manag., vol. 36, no. 3-4, pp. 384-403, Feb. 2020, https://doi.org/10.1080/0267257x.2019.1702082.

[76] D. Sprott, S. Czellar, and E. Spangenberg, "The Importance of a General Measure of Brand Engagement on Market Behavior: Development and Validation of a Scale," J. Mark. Res., vol. 46, no. 1, pp. 92-104, Feb. 2009, https://doi.org/10.1509/jmkr.46.1.92.

[77] J. van Doorn et al., "Customer Engagement Behavior: Theoretical Foundations and Research Directions,” J. Serv. Res., vol. 13, no. 3, pp. 253-266, Aug. 2010, https://doi.org /10.1177/1094670510375599.

[78] R. Hanna, A. Rohm, and V. L. Crittenden, "We're all connected: The power of the social media ecosystem," Bus. Horiz., vol. 54, no. 3, pp. 265-273, 2011, https://doi.org/10.1016/j. bushor.2011.01.007.

[79] J. U. Islam and Z. Rahman, "The transpiring journey of customer engagement research in marketing," Manag. Decis., vol. 54, no. 8, pp. 2008-2034, Sep. 2016, https://doi.org/10. 1108/md-01-2016-0028.

[80] L. D. Hollebeek, "Demystifying customer brand engagement: Exploring the loyalty nexus," J. Mark. Manag., vol. 27, no. 7-8, pp. 785-807, 2011, https://doi.org/10.1080/0267257x. 2010.500132.

[81] P. Harrigan, U. Evers, M. P. Miles, and T. Daly, "Customer engagement and the relationship between involvement, engagement, self-brand connection and brand usage intent," J. Bus. Res., vol. 88, no. June, pp. 388-396, 2018, https://doi.org/10.1016/j.jbusres.2017.11.046.

[82] D. Langaro, P. Rita, and M. de Fátima Salgueiro, "Do social networking sites contribute for building brands? Evaluating the impact of users' participation on brand awareness and brand attitude," J. Mark. Commun., vol. 24, no. 2, pp. 146-168, 2018, https://doi.org/10.1080/ 13527266.2015 .1036100$.

[83] A. Pansari and V. Kumar, "Customer engagement: the construct, antecedents, and consequences,” J. Acad. Mark. Sci., 2017, https://doi.org/10.1007/s11747-016-0485-6.

[84] E. Jaakkola and M. Alexander, "The Role of Customer Engagement Behavior in Value CoCreation: A Service System Perspective,” J. Serv. Res., vol. 17, no. 3, pp. 247-261, 2014, https://doi.org/10.1177/1094670514529187.

[85] S. Bazi, R. Filieri, and M. Gorton, "Customers' motivation to engage with luxury brands on social media,” J. Bus. Res., vol. 112, no. February, pp. 223-235, 2020, https://doi.org/10. 1016/j.jbusres.2020.02.032.

[86] P. Garg, B. Gupta, S. Dzever, U. Sivarajah, and V. Kumar, "Examining the Relationship between Social Media Analytics Practices and Business Performance in the Indian Retail and IT Industries: The Mediation Role of Customer Engagement," Int. J. Inf. Manage, vol. 52, no. January, p. 102069, 2020, https://doi.org/10.1016/j.ijinfomgt.2020.102069.

[87] R. Lins Rodrigues, J. Luis Cavalcanti Ramos, J. Carlos Sedraz Silva, and A. Sandro Gomes, "Discovery engagement patterns MOOCs through cluster analysis," IEEE Lat. Am. Trans., vol. 14, no. 9, pp. 4129-4135, Sep. 2016, https://doi.org/10.1109/tla.2016.7785943. 
Paper-Micro-learning Platforms Brand Awareness Using Social-media Marketing and Customer...

[88] V. L. Crittenden and W. F. Crittenden, "Digital and Social Media Marketing in Business Education: Implications for Student Engagement," Journal of Marketing Education, vol. 37, no. 3. SAGE Publications Inc., pp. 131-132, 01-Dec-2015, https://doi.org/10.1177/02734 75315588112.

[89] A. A. Alghamdi and M. Plunkett, "Perceptions of Saudi Male and Female Postgraduate Students Regarding the Impact of Social Networking Sites and Apps on their Academic Life," Int. J. Emerg. Technol. Learn., vol. 13, no. 05, pp. 19-40, Apr. 2018, https://doi.org 110.3991/ijet.v13i05.7981.

[90] S. F. M. Beckers, J. van Doorn, and P. C. Verhoef, "Good, better, engaged? The effect of company-initiated customer engagement behavior on shareholder value," J. Acad. Mark. Sci., vol. 46, no. 3, pp. 366-383, May 2018, https://doi.org/10.1007/s11747-017-0539-4.

[91] C. M. Harmeling, J. W. Moffett, M. J. Arnold, and B. D. Carlson, "Toward a theory of customer engagement marketing," J. Acad. Mark. Sci., 2017, https://doi.org/10.1007/ s11747-016-0509-2.

[92] R. Venkatesan, "Executing on a customer engagement strategy," Journal of the Academy of Marketing Science, vol. 45, no. 3, 2017.

[93] A. A. Barreda, A. Bilgihan, K. Nusair, and F. Okumus, "Generating brand awareness in Online Social Networks," Comput. Human Behav., vol. 50, pp. 600-609, May 2015, https:// doi.org/10.1016/j.chb.2015.03.023.

[94] V. Charles and T. Gherman, "Student-based brand equity in the business schools sector: An exploratory study," New Educ. Rev., vol. 42, no. 4, pp. 165-176, 2015, https://doi.org/ 10.15804/tner.2015.42.4.14.

[95] B. Qi and L. Mackie, "Utilising social media technology to raise brand awareness in higher education," WEBIST 2014 - Proc. 10th Int. Conf. Web Inf. Syst. Technol., vol. 1, pp. 400405, 2014, https://doi.org/10.5220/0004965804000405.

[96] P. Herbig and J. Milewicz, "The Relationship of Reputation and Credibility to Brand Success," J. Consum. Mark., vol. 10, no. 3, pp. 18-24, 1993, https://doi.org/10.1108/eum000 $\underline{0000002601 .}$.

[97] R. Huang and E. Sarigöllü, "How brand awareness relates to market outcome, brand equity, and the marketing mix," J. Bus. Res., vol. 65, no. 1, pp. 92-99, Jan. 2012, https://doi.org/10. 1016/j.jbusres.2011.02.003.

[98] E. K. Macdonald and B. M. Sharp, "Brand Awareness Effects on Consumer Decision Making for a Common, Repeat Purchase Product: A Replication," J. Bus. Res., vol. 48, no. 1, pp. 5-15, Apr. 2000, https://doi.org/10.1016/s0148-2963(98)00070-8.

[99] W. D. Hoyer and S. P. Brown, "Effects of Brand Awareness on Choice for a Common, Repeat-Purchase Product," J. Consum. Res., vol. 17, no. 2, p. 141, Sep. 1990, https://doi.org/ $10.1086 / 208544$.

[100] H. Oh, "The Effect of Brand Class, Brand Awareness, and Price on Customer Value and Behavioral Intentions,” J. Hosp. Tour. Res., vol. 24, no. 2, pp. 136-162, May 2000, https:// doi.org/10.1177/109634800002400202.

[101] J. R. Rossiter and L. Percy, Advertising and promotion management. New York, NY, England: Mcgraw-Hill Book Company, 1987.

[102] K. L. Keller, "Reflections on customer-based brand equity: perspectives, progress, and priorities," AMS Rev., vol. 6, no. 1-2, pp. 1-16, 2016, https://doi.org/10.1007/s13162-0160078-z.

[103] R. Pappu, R. W. Cooksey, and P. G. Quester, "Consumer-based brand equity: improving the measurement - empirical evidence,” J. Prod. Brand Manag., vol. 14, no. 3, pp. 143-154, May 2005, https://doi.org/10.1108/10610420510601012. 
Paper-Micro-learning Platforms Brand Awareness Using Social-media Marketing and Customer...

[104] D. A. Aaker, Managing Brand Equity: Capitalizing on the Value of a Brand Name, 1st ed. Free Press, 1991.

[105] K. L. Keller, "Managing Brands for the Long Run: Brand Reinforcement and Revitalization Strategies," Calif. Manage. Rev., vol. 41, no. 3, pp. 102-124, Apr. 1999, https://doi.org/10. 2307/41165999.

[106] L. Radder and W. Huang, "High-involvement and low-involvement products: A comparison of brand awareness among students at a South African university," J. Fash. Mark. Manag., vol. 12, no. 2, pp. 232-243, 2008, https://doi.org/10.1108/13612020810874908.

[107] A. H. Tolba and S. S. Hassan, "Linking customer-based brand equity with brand market performance: A managerial approach,” J. Prod. Brand Manag., vol. 18, no. 5, pp. 356-366, Aug. 2009, https://doi.org/10.1108/10610420910981837.

[108] A. Brewer and J. Zhao, "The impact of a pathway college on reputation and brand awareness for its affiliated university in Sydney," Int. J. Educ. Manag., vol. 24, no. 1, pp. 34-47, Jan. 2010, https://doi.org/10.1108/09513541011013033.

[109] X. Chen, E. Xia, and W. Jia, "Utilisation Status and User Satisfaction of Online Education Platforms," Int. J. Emerg. Technol. Learn., vol. 15, no. 19, pp. 154-170, Oct. 2020, https:// doi.org/10.3991/ijet.v15i19.17415.

[110] K. T. Tran, P. V. Nguyen, H. T. S. Do, and L. T. Nguyen, "University students' insight on brand equity," Manag. Sci. Lett., vol. 10, no. 9, pp. 2053-2062, 2020, https://doi.org/10. 5267/j.msl.2020.2.006.

[111] J. Casanoves-Boix, "Evolution of marketing in higher education: Educational brand capital," Esic Mark. Econ. Bus. J., vol. 48, pp. 69-93, https://doi.org/10.7200/esicm.156.0481.2.

[112] T. Tsiatsos, N. Politopoulos, P. Stylianidis, V. Zilidou, E. Ziagkas, and S. Douka, "Evaluating a Coaching MOOC Course to Support Dual Career of Athletes," in Advances in Intelligent Systems and Computing, 2021, vol. 1192 AISC, pp. 401-409, https://doi.org/ 10.1007/978-3-030-49932-7 39.

[113] H. Chahal and A. Rani, "How trust moderates social media engagement and brand equity," J. Res. Interact. Mark., 2017, https://doi.org/10.1108/jrim-10-2016-0104.

[114] R. Algharabat, N. P. Rana, A. A. Alalwan, A. Baabdullah, and A. Gupta, "Investigating the antecedents of customer brand engagement and consumer-based brand equity in social media," J. Retail. Consum. Serv., vol. 53, Mar. 2020, https://doi.org/10.1016/j.jretconser 2019.01.016.

[115] J. Kumar, "Understanding customer brand engagement in brand communities: an application of psychological ownership theory and congruity theory," Eur. J. Mark., 2020, https://doi. org/10.1108/ejm-04-2018-0290.

[116] J. Pharr, "Best Practices in Digital Content Marketing for Building University Brands," Assoc. Mark. Theory Pract. Proc. 2019, Jan. 2019, Accessed: 14-Mar-2021. [Online]. Available: https://digitalcommons.georgiasouthern.edu/amtp-proceedings 2019/8.

[117] S. Palmer, "Characterisation of the use of Twitter by Australian Universities," J. High. Educ. Policy Manag., vol. 35, no. 4, pp. 333-344, Aug. 2013.

[118] J. Pringle and S. Fritz, "The university brand and social media: Using data analytics to assess brand authenticity," J. Mark. High. Educ., vol. 29, no. 1, pp. 19-44, Jun. 2019, https://doi.org /10.1080/08841241.2018.1486345.

[119] A. Palmer, N. Koenig-Lewis, and Y. Asaad, "Brand identification in higher education: A conditional process analysis," J. Bus. Res., vol. 69, no. 8, pp. 3033-3040, Aug. 2016, https:// doi.org/10.1016/j.jbusres.2016.01.018.

[120] N. Chokpitakkul and S. Anantachart, "Developing and validating a scale of consumer-based brand equity for SMEs: evidence from Thailand,” J. Small Bus. Enterp. Dev., vol. 27, no. 3, pp. 383-404, May 2020, https://doi.org/10.1108/jsbed-04-2019-0138. 
[121] I. P. Chiang, S. E. Tu, and L. H. Wang, "Exploring the social marketing impacts of virtual brand community engagement," Contemp. Manag. Res., vol. 14, no. 2, pp. 143-164, Aug. 2018, https://doi.org/10.7903/cmr.18086.

[122] V. D. de Rada, "Ventajas e inconvenientes de la encuesta por internet," Papers, vol. 97, no. 1, pp. 193-223, 2012, https://doi.org/10.5565/rev/papers/v97n1.71.

[123] J. Ye, D. Marinova, and J. Singh, "Strategic change implementation and performance loss in the front lines," J. Mark., vol. 71, no. October, pp. 156-171, 2007, https://doi.org/ 10.1509/jmkg.71.4.156.

[124] C. Leckie, M. W. Nyadzayo, and L. W. Johnson, "Antecedents of consumer brand engagement and brand loyalty,” J. Mark. Manag., vol. 32, no. 5-6, pp. 558-578, 2016, https: //doi.org/10.1080/0267257x.2015.1131735.

[125] H. Wold, "Soft modeling: the basic design and some extensions," in Systems Under Indirect Observation: Causality, Structure, Prediction, vol. 2, 1982, pp. 1-54.

[126] C. Ringle, J. Becker, and S. Wende, "SmartPLS3," Handb. Mark. Res., no. January, pp. 1329, 2014, https://doi.org/10.1007/978-3-319-05542-8 15-1.

[127] T. K. Dijkstra and J. Henseler, "Consistent and asymptotically normal PLS estimators for linear structural equations,” 2012. Accessed: 13-Aug-2020. [Online]. Available: https:// www.rug.nl/staff/t.k.dijkstra/Dijkstra-Henseler-PLSc-linear.pdf, https://doi.org/10.1016/j. csda.2014.07.008.

[128] Sarstedt M., Ringle C.M., and Hair J.F., "Partial Least Squares Structural Equation Modeling ," Handb. Mark. Res. Springer, Cham, 2017, https://doi.org/10.1007/978-3-31905542-8 15-1.

[129] M. Sarstedt, J. F. Hair, J. H. Cheah, J. M. Becker, and C. M. Ringle, "How to specify, estimate, and validate higher-order constructs in PLS-SEM," Australas. Mark. J., vol. 27, no. 3, pp. 197-211, Aug. 2019, https://doi.org/10.1016/j.ausmj.2019.05.003.

[130] P. Duarte and S. Amaro, "Methods for modelling reflective-formative second order constructs in PLS: An application to online travel shopping," J. Hosp. Tour. Technol., vol. 9, no. 3, pp. 295-313, Oct. 2018, https://doi.org/10.1108/jhtt-09-2017-0092.

[131] C. Crocetta et al., "Higher-Order PLS-PM Approach for Different Types of Constructs," Soc. Indic. Res., 2020, https://doi.org/10.1007/s11205-020-02563-w.

[132] R. P. Bagozzi and Y. Yi, "On the evaluation of structural equation models," J. Acad. Mark. Sci., vol. 16, no. 1, pp. 74-94, Mar. 1988, https://doi.org/10.1007/BF02723327.

[133] J. F. Hair, M. Sarstedt, L. Hopkins, and V. G. Kuppelwieser, "Partial least squares structural equation modeling (PLS-SEM): An emerging tool in business research," Eur. Bus. Rev., vol. 26, no. 2, pp. 106-121, 2014, https://doi.org/10.1108/ebr-10-2013-0128.

[134] T. K. Dijkstra and J. Henseler, "Consistent partial least squares path modeling," MIS Quarterly: Management Information Systems, vol. 39, no. 2. University of Minnesota, pp. 297-316, 01-Jun-2015, https://doi.org/10.25300/misq/2015/39.2.02.

[135] J. Henseler, C. M. Ringle, and M. Sarstedt, "A new criterion for assessing discriminant validity in variance-based structural equation modeling," J. Acad. Mark. Sci., vol. 43, no. 1, pp. 115-135, Aug. 2014, https://doi.org/10.1007/s11747-014-0403-8.

[136] J. A. Marin-Garcia and R. Alfalla-Luque, "Key Issues on Partial Least Squares (PLS) in Operations Management Research: A Guide to Submissions," J. Ind. Eng. Manag., vol. 12, no. 2, pp. 219-240, 2019, https://doi.org/10.3926/jiem.2944.

[137] M. Sarstedt, C. M. Ringle, and J. F. Hair, "Partial Least Squares Structural Equation Modeling," in Handbook of Market Research, Cham: Springer International Publishing, 2017, pp. 1-40. 
[138] J. Henseler, C. M. Ringle, and M. Sarstedt, "A new criterion for assessing discriminant validity in variance-based structural equation modeling," J. Acad. Mark. Sci., vol. 43, no. 1, pp. 115-135, 2014, https://doi.org/10.1007/s11747-014-0403-8.

[139] J. Cohen, Statistical Power Analysis for the Behavioral Sciences. Routledge, 2013.

[140] J. F. Hair, G. T. M. Hult, C. Ringle, and M. Sarstedt, A Primer on Partial Least Squares Structural Equation Modeling (PLS-SEM) | SAGE Publications Inc, 2nd ed. Thousand Oaks: Sage, 2017, https://doi.org/10.3926/oss.37.

[141] C. Nitzl, J. L. Roldan, and G. Cepeda, "Mediation analysis in partial least squares path modelling, Helping researchers discuss more sophisticated models," Ind. Manag. Data Syst., vol. 116, no. 9, pp. 1849-1864, 2016, https://doi.org/10.1108/imds-07-2015-0302.

[142] C. Seo and J. W. Park, "A study on the effects of social media marketing activities on brand equity and customer response in the airline industry," J. Air Transp. Manag., vol. 66, no. August 2017, pp. 36-41, 2018, https://doi.org/10.1016/i.jairtraman.2017.09.014.

[143] E. Choi, E. Ko, and A. J. Kim, "Explaining and predicting purchase intentions following luxury-fashion brand value co-creation encounters," J. Bus. Res., vol. 69, no. 12, pp. 58275832, 2016, https://doi.org/10.1016/i.jbusres.2016.04.180.

[144] J. Kim and K. H. Lee, "Influence of integration on interactivity in social media luxury brand communities,” J. Bus. Res., vol. 99, no. September, pp. 422-429, 2019, https://doi.org/10. 1016/j.jbusres.2017.10.001.

[145] R. Huerta-Álvarez, J. J. Cambra-Fierro, and M. Fuentes-Blasco, "The interplay between social media communication, brand equity and brand engagement in tourist destinations: An analysis in an emerging economy," J. Destin. Mark. Manag., vol. 16, Jun. 2020, https://doi. org/10.1016/j.jdmm.2020.100413.

[146] M. Raza, S. Salleh, B. Tariq, R. S. Altayyar, and H. Shaari, "Investigating the effects of customer-based brand equity on turnover intentions with mediating effect of customer citizenship behavior," Manag. Sci. Lett., vol. 10, no. 2, pp. 279-286, 2020, https://doi.org /10.5267/j.msl.2019.9.004.

[147] J. J. Gish-Lieberman, A. Tawfik, and J. Gatewood, "Micro-Credentials and Badges in Education: a Historical Overview," TechTrends, vol. 65, no. 1, pp. 5-7, Jan. 2021, https://doi.org/10.1007/s11528-020-00567-4.

\section{Authors}

Alejandro Mujica-Luna has a degree in Communication and Marketing. His research interests are related to Digital Marketing and E-Learning. Currently, he is working as Digital Marketing consultant.

Esteban Villanueva has a degree in Communication and Marketing. His research interests are related to Entrepreneurship and Digital Transformation. His passion has led him to research Social Entrepreneurship in Peru.

Manuel Luis Lodeiros-Zubiria is a marketing professor at Universidad Peruana de Ciencias Aplicadas, Peru. He is enrolled to obtain a PhD at Universidad de Cordoba, Spain. His main research areas are consumer behaviour in developing countries related to Fast Moving Consumer Goods, Banking, Tourist, E-Learning and E-commerce.

Article submitted 2021-04-15. Resubmitted 2021-06-16. Final acceptance 2021-05-17. Final version published as submitted by the authors. 